\title{
Farewell to the Self: Between the Letter and the Self-Portrait
}

\author{
Maria Tamboukou, University of East London, UK
}

\begin{abstract}
In this paper I consider interfaces between visual and textual representations of the female self in art. I am looking in particular at Gwen John's self-portraits and the letters revolving around them. In this context, there are three thematic areas that I explore: a) questions around portraiture in general and the self-portrait in particular, b) connections between visual images and textual narratives in life-writing research and c) genealogical lines in John's self-representation through her paintings and letters. What I suggest is that John's self-portraits become events for playing with different modalities of selfrepresentation and experimenting with other ways of painting the self, while her letters become texts destabilizing and interrogating conventions of reading the visual. What I finally argue is that the visual turn in narrative research needs to consider carefully discourses and debates in the field of art histories, while the latter have to become more informed in the nuances of life narrative research.
\end{abstract}

Key words: self-portraits, letters, life narratives, Gwen John, visual turn

How dreadful though that you should think that girl is sitting on the table and that she is me! ... You are so right about that head, I tried to make it look like a vierge of Dürer, it was a very silly thing to do. I did it because I didn't want to have my own face there. The picture I have done for Mr Quinn is the same pose and I have put my own face in and it is more fitting. ${ }^{1}$

In the above extract from a letter written on October $15^{\text {th }}, 1911$, Gwen John, an expatriate Welsh artist who mostly lived and worked in Paris², has an epistolary conversation with her friend Ursula Tyrwhitt about her painting A Lady Reading. ${ }^{3}$ The picture depicts a young woman in her room, reading a book by the open window. She is wearing a dark burgundy blouse and a black skirt, while her right foot is elevated and rests on a wicker chair. The figure seems to be slightly leaning on a simple pine table and one might have thought that she was sitting on the edge of it, which is not the case as we know from the comment in John's own letter above. There is little decoration in the room apart from the pine table and the wicker chair: a red-and-white checked curtain, a little bookshelf just above the table and three pictures hanging on the wall. Being frustrated and disappointed by the decision 
to depict the face of the figure as a Dürer's Madonna, John painted a similar picture soon after: Girl Reading at the Window. ${ }^{4}$ These two pictures only differ in details: the figure in Girl Reading is wearing an all black dress and a black bow in her hair; there is a lace curtain and a second chair at the corner of the room; finally there is only one picture hanging on the wall behind the head of the standing figure, which is John's face this time, as also mentioned in the letter above.

We know for sure that this rather intellectual milieu with the pictures, the books, the inexpensive art objects, the wicker chair and the lace curtains is the artists' own room in Paris. Simple as they are, these two paintings have lent themselves to a number of interpretations and discussions. Writer Eva Figes has suggested that the bare room represents John's poverty and the harsh conditions of her life as a single woman artist struggling to survive. $(1993,74)$ Art critic, Alicia Foster has made connections between John's conversion to Catholicism in 1913 and 'the depictions of sacred figures and events in the work of Catholic artists.' $(1999,52)$

The plainness of the room has also been discussed in the context of artistic trends and influences upon John's work. In Foster's (43) analysis, the simplicity of the décor in John's interiors and certain inexpensive objects, like the wicker chair or the pine table that recur in many of her paintings, are signs of the artistic bohemian imagery and lifestyle she was adhering to. It was also a style very close to painters of the Camden Town Group ${ }^{5}$. Foster has also pointed out the Symbolist influences upon John's work, particularly the way domestic objects, like the lace curtain, would be represented as extraordinary or 'sources of poetry and mystery in Symbolist art and literature.' (47) Moreover, these two paintings alongside other interiors have become part of the discursive constitution of the artist as a woman who led an interior life and have fuelled feminist discussions and arguments around the possibility or rather the impossibility of the flâneuse, the wandering female figure of the urban spaces of modernity. (Wolff, 1994)

What is finally intriguing is that both pictures, the Lady and the Girl, have been described as 'self-portraits.' In her catalogue raisonné of John's paintings, Cecily Langdale $(1987,141)$ notes that 'A Lady Reading has always been called a self portrait'. Langdale (142) further refers to Quinn's sale catalogue describing the Girl Reading as a self portrait. In disagreement with Langdale, Foster has argued that the artist's face and the familiar surroundings appearing in the pictures cannot make them self-portraits: 'there are none of the compositional signs which indicate to the viewer that the painting [Girl reading at the Window] should be interpreted as a self-portrait.' $(1999,55)$

As I have shown so far, John's paintings have created a complex web of discussions, interpretations and arguments that span across disciplinary interests and fields; they thus form a matrix of concepts, ideas and discourses around the problem of how visual and textual images can be brought together in a genealogical exploration of the female self in art. What I want to do in this paper is to unravel some of these interrelated lines of analysis, particularly focusing on interfaces between self-portraits and letters. The former cannot be simply 
used as illustrations of biographical details or theoretical arguments, while the latter cannot be reduced to captions or subtitles for paintings. My argument is that there is a need for more interdisciplinary discussions between narrative analyses, visual studies, art histories and biographical research. In this context, there are three thematic paths that I want to follow: a) explore questions around portraiture in general and the self-portrait in particular, b) make connections between visual images and textual narratives in life-writing research and c) trace genealogical lines in John's self-representation through her paintings and letters.

\section{Talking of Genres: the Self-Portrait}

As Shearer West has noted, the self-portrait has one of the most fascinating and complex histories within the whole genre of portraiture. $(2004,163)$ This history goes back to the late fifteenth, early sixteenth centuries and to the Venetian invention of flat mirrors that created a turning point, an event in the self-representation of the artist. This was also the era of what Foucault (2000) has famously described as the invention of man as a knowing subject and an object of this knowledge. The turn of the sixteenth century was therefore a critical period of increasing self-consciousness and reflexivity in the history of though that created conditions of possibility for the proliferation of auto/biographical narratives and of all sorts of textual and visual representations of the self in quest.

In this matrix of complex and often antagonistic discourses around the self and the possibilities and ethico-aesthetic values of knowing and representing it, artists in different periods have used self-portraiture for different reasons: to gain a rite of passage in the artworld, to promote their artistic abilities, to attract commissions and patronages, to experiment with different techniques, methods and media, to ultimately emerge as sovereign individuals. ${ }^{6}$ Self-portraiture has also opened up possibilities for transcendence, pointing to the divine dimension of the artist, as in the art of Albrecht Dürer, who initiated the tradition of the self-portrait as a visual psychograph.

Self-portraiture is thus related to a life or a real person, the artist herself, but the way this life or this person has been represented varies according to the period, artistic conventions and trends, social and cultural expectations of the era, the artist's talent and genius, and of course the patron's or the market's expectations and demands. Similarly self-portraits have been interpreted and analyzed from a variety of theoretical positions in philosophy and trends in art history. A critical question that has been raised is whether a self-portrait should be defined as such, by the act of recognition it mobilizes to the viewer or by the intention of the artist. In this context should John's paintings, A Lady and the Girl Reading, be taken as self-portraits? This is a question I now want to rethink.

Gali Weiss has noted that 'the practice of portraiture relies heavily on representation-representing a presence.' $(2009,51)$ This presence has to be recognised, Woodall $(1996)$ has argued, since 'what is mobilized by the artist is the viewer's act of recognition.' (in Weiss, $2009,51)$ In this light, Girl Reading can be conceived as a self-portrait since it has mobilized recognition in the mind of the artist's brother as Langdale has suggested above. The prob- 
lem is more complicated however, should the intention of the artist be considered as more important. Richard Brilliant (1991) for instance has argued that 'the viewer's awareness of the artwork as a portrait is distinctly secondary ... it is the artist who establishes the category 'portrait.' (in Weiss 2009, 35) Whether the portrait depends on the artist's intention or the viewer's interpretation, what is highly problematic in both views, according to Weiss, is the overall conception that 'the function of the portrait is to fix the presence of its referent, and the success of the artist to do so lies in her capacity to recognise and 'capture' an essentialized form of that presence.' (35) Moving away from the necessity to pin down the subject, Ludmilla Jordanova (2005) has suggested that the study of self-portraiture is more important in offering insights in how artistic processes unfold and artistic identities are formed, rather than in capturing any kind of autobiographical truth about the subject of the artist.

Interpreting the self -portrait thus requires much more than a juxtaposition of narratives, visual images and titles in exhibition catalogues; it calls for close attention to the historical, social and cultural contexts that condition the emergence of the work of art under consideration. The interpretation should therefore be particularly attentive to the processes of recontextualization: what happens to the work of art when it is placed in a different context of analysis and understanding and how this recontextualization can create new levels of meaning that are transdiciplinary rather than, naïve, reductionist or confusing. As Jordanova $(2005,45)$ aptly notes:

Interpreting self-portraits requires an elaborate historical sense. Such images are made in the artists' here and now-necessarily a complex swirl of forces, including their aspirations and anxieties about competition, whether actual or imagined, strategies for creating and advancing a 'reputation', as well as their immediate domestic and social relationships, geographical location and economic needs. They are also produced out of artists' senses of visual models to be emulated, revered forbears, influential teachers and masters. In other words, artists themselves often have a vivid awareness, that can be termed 'historical', of what has gone before, and in making it manifest, as many did in their self-portraits, they speak to contemporaries about their debts and their filiations and lay down deposits for future generations to examine.

Jordanova's suggestions initiate lines of analysis that are more useful than the question of whether John's paintings were 'really' self-portraits. Seen in the context of her overall work and particularly her later paintings, this question becomes indeed insignificant. John was never really interested in the identity of the sitter: in her later portraits we don't even know who the sitter is. John's models, including herself, were not treated as individuals but as 'a set of pictorial problems requiring solution.' (Langdale1987, 89) In the light of Jordanova's suggestion above, John's self-portraits were also opportunities for 'visual models to be emulated' and influential teachers and masters to be acknowledged. In her letters, John has in- 
deed shown awareness of her own historicity as an artist, by explicitly stating her debt to Dürer as in the letter cited above.

In following a great master, who was also a leading figure in the history of the psychological portrait (Koerner 2005), John was inevitably influenced by Dürer's own self-portraits as Christ, what commentators have called his 'Christomorphism.' Koerner has particularly pointed to an analogy identified between Christ as 'God the artificer' and Dürer as the artist in his divinity, in modern commentaries on his work. $(2005,71)$

Interestingly enough in her notebooks, John has referred to herself as 'God's little artist', ${ }^{\text {a }}$ line much noted and discussed by commentators of her own work, always in relation to her religiosity and particularly her conversion to Catholicism. As Foster has explicitly put it: 'Her spiritual involvement in Catholicism had its parallel in her work, a connection made in her description of herself as 'God's little artist'. $(1999,52)$ Relevant as such connections might be, what I think is more interesting about John's well-noted entry is the way this phrase shows her adherence to a certain historical tendency in the constitution of the persona of the artist: a transcendental figure, rising beyond earthy concerns and attaining to the divine. Indeed, short and elliptical as it is, John's notebook entry 'God's little artist: a seer of strange beauties, a teller of harmonies, a diligent worker', is a sign of how she was consciously attempting to situate herself in Dürer's divine universe. It is this trail in the history of art that John was following in trying to make sense of herself as an artist and this was independent of the fact that she had become a Catholic. What I therefore argue is that John's constitution as an artist, as revealed in her paintings, but also in her letters and notebooks, is related to her religious beliefs but is not determined by them.

Moreover as a woman artist, John was grappling with the difficulties of adhering to the generic conventions of a long male dominated tradition in self-portraiture. "Women artists producing self-portraits encountered a variety of masculine stereotypes with which they interacted in order to make work', Marsha Meskimmon $(1996,10)$ has argued. In this light John's decision to paint the face of the female figure in A Lady Reading as a Dürer's Madonna could be seen as what I will call, Virginmorphism-a gender-bending of an old master's idea and technique, rather than as a biographical sign of her conversion to Catholicism.

John's artistic experiments with seeing, knowing and representing the self should therefore not be conflated with biographical details or reduced to her religious beliefs or attitudes at the time. I have discussed elsewhere, how John is emerging as a nomadic subject, difficult and impossible to be pinned down as a coherent and fixed identity and I have also indicated the inherent error of creating linear causalities between what she wrote or painted and who she was. (Tamboukou 2008) In this sense John cannot be constrained within the identity position of a single woman on the verge of surviving (Figes 1993, 74) or that of a 'Catholic artist.' (Foster 1999, 53) It is in the same vein that she always evades subjectification as a talented Slade girl, a modernist artist, a bohemian, a recluse, a hysteric passionate lover or a spinster surrounded by cats. Of course John was moving in the vicinities of dif- 
ferent subject positions, but would never inhabit any of them permanently. Her selfportraits offer visual images of her nomadic passages but have to be considered alongside her letters, so that a cartography of her subjectivity can be charted. But what is the relationship between self-portraiture and auto/biographical documents such as letters? It is this question that I now want to take up, moving to the second thematic path of this paper as delineated above, the interface between the visual and the textual.

\section{Portraiture as a Visual Form of Life Writing}

Jens Brockmeier $(2001,255)$ has argued that 'narrative should not be understood as a language entity, but in a more general sense as the ability or capacity to tell a story. A narrative text in this view is a text in which one or more agents tell a story in a particular medium'; in this sense all narratives are relational acts par excellence. The medium in Brockmeier's analysis 'can be language as well as imagery, sound, spatial construction or a combination thereof.' (255) Brockmeier emphatically notes that in this light, 'it is particularly revealing to look at portraiture as a visual form of life writing.' (255) 'But how can a life narrative become an iconic artefact?' Brockmeier (255) has asked. In response to this question, he has put forward the argument that

... pictures and words, imagery and narrativity are interwoven in one and the same semiotic fabric of meaning. They are overlapping trajectories with the same symbolic space, a space of meaning in which our experience takes place and in which we try to make sense of the world. (255)

Brockmeier bases the argument above on the assertion that painting is primarily an iconic symbol system. Undoubtedly there is merit in this proposition. But what is the semiotic regime that Brockmeier's analysis draws upon? Does it concern the Saussurean linear signified-signifier relationship? The latter is neither self-evident nor unproblematic.

Things become even more complicated, if we consider portraits on the plane of Peircian semiotics, in which case, Brockmeier's assertion that 'painting is an iconic symbol system' needs to be further unravelled. It is particularly Charles Peirce's triadic sign relation of the sign, the object and the interpretant as well as his tripartite classification of signs as icons, indices and symbols that has been followed in certain strands of the portrait literature. ${ }^{8}$ It is thus lines of Peircian semiotics that I now want to look into.

Signs in Peirce's theory constitute the world, thinking is sign and even human beings are signs. How does the sign relation function? Peirce introduces the role of the interpretant in the sign relation and in this sense a triadic relation is configured between the sign or representamen, the object, which is what is being represented and the interpretant. 'A sign receives its meaning by being interpreted by a subsequent thought or action [and] it is only in relation to a subsequent thought ... the interpretant that the sign attains meaning.' (Hoops 
1991, 7) Within the cycle of the triadic sign relation, Peirce further introduces a tripartite taxonomy of signs depending on the indispensability of the presence of the interpretant, and the object in the configuration of the relation:

A sign is either an icon, an index, or a symbol. An icon is a sign which would possess the character which renders it significant even though its object had no existence; [...] An index is a sign, which would at once lose the character, which makes it a sign if its object were removed, but would not lose that character if there were no interpretant [...] A symbol is a sign, which would lose the character that renders it a sign if there were no interpretant. (Peirce 1991, 239-40)

In explicating Peircian semiotics, West has noted that 'an icon looks like the thing it represents, an index draws attention to something outside the representation and a symbol is a seemingly arbitrary sign that is, by cultural convention connected to a particular object.' (2004, 41) Drawing on the explication above, West has subsequently argued that the portrait has qualities of all three typologies of signs above: 'it resembles the object of representation (icon), it refers to the act of sitting (index) and it contains gestures, expressions and props that can be read with knowledge of social and cultural conventions (symbol).' (41) I would note here however that participation in all qualities of the Peircian tripartite taxonomy could apply to a wide range of signs and is thus not particularly helpful for the analysis of portraiture. West has of course pointed to the fact that 'the indexical qualities of portraiture are particularly notable.' I would extend this statement to simply argue that the portrait is an index in the Peircian taxonomy delineated above, since to paraphrase Peirce, without the sitter, there would have been no portrait. Moreover, as an index the portrait does not depend on the interpretant: there is a figure there, whether anybody has the sense to attribute it to a particular sitter or not, and this is what is particularly significant for a portrait or a self-portrait to be recognized as such.

Drawing on Peirce's semiotics therefore, my contention is that a portrait-as well as any text-is participating in an infinite series of sign relations and thus its interpretation can never close off. If we are to apply Peircian semiotics to the debate about John's last selfportraits as delineated above, Langdale's interpretation of the Girl Reading and A Lady Reading, as self-portraits is meaningful in the sense that it goes via the interpretants-John's brother and patron in this case-who recognized John's figure in the paintings and thus took them as self-portraits. Similarly though, Foster's counter-argument that these paintings cannot be considered as the artist's self-portrait can also stand as 'true' since the interpretant here is the mental state of the art critic who cannot recognize compositional signs of the genre of self-portraiture in these paintings. What I would therefore add here is that this openness also leaves space for analyses that go beyond phenomenological approaches to the interpretation of paintings, and trace forces that are released in the canvas rather than being illustrative or narrative elements that appear on it. (see Tamboukou, in press) 
In this light Brockmeier's question above, about how a life narrative can become an iconic artefact $(2001,255)$ is reversed in my analysis. I would rather raise the question of whether and how an iconic artefact can be read as a life narrative, how it can transgress the boundaries of illustration and narration and what the role of epistolary narratives in this process is. Brockmeier argues that in recontextualizing portraiture within a narrative plane, we need to consider, 'three possible narrative points of view, or shall we say voices: the portrayed man, the viewer, and the painter. So who is telling the story? And to whom?' (2001, 255) There is a strong analogy here between the Peircian triadic sign relation-object, sign, interpretant-and the classic tripartite relation of portraiture-the sitter, the painter and the viewer. What happens to the latter if considered within the Peircian semiotics however is that it initiates a series of sign relations ad infinitum. The answer to the question of "who is telling the story and to whom' can never be conclusive: it will always generate new interpretants within the triadic cycle of signs relations as discussed above.

Moving beyond the constraints of representation and recognition, both in her art practice and her theoretical work, Weiss (2009) has argued that portraiture should 'move from a referential function to a performative one, locating meaning and signification not in the fixed presence of a sitter/subject or an artist, but in the shifting subject relations between artist, subject and viewer.' What I propose then is that it is the power of the image as a Peircian index to generate meaning, draw the viewer's attention to something outside the representation and inspire her to imagine worlds beyond what has been or can be merely represented, that Weiss's suggestion is about. What is stressed here is the fluidity of the relations between subject, artist and viewer and this is grounded of course in the continuously changing role of the interpretant, as already discussed. In this context, the experience of the viewer becomes part of the performative nature of portraiture:

When a portrait is non-essentialist and performatory, it invites the spectator to negotiate the subjectivity of vision, poetry, and memory. The spectator becomes an integral part of the identity of the portrait, not by recognising the specific individual behind the portrait, but through recognising a relational experience of identification - through the mark-making or artistic medium, through openness or transience of image, or 'deferred' image, through concept and poetic imagination. (Weiss, 2009, 104)

In this light, the portrait is not fixed as an artistic medium through which the essence of the subject is represented either in her intellectual, psychological or bodily splendour, or abjection. Neither can the portrait be taken as an artistic plane where the presence of the sitter is illuminated or 'truth' is enhanced. Without precluding these possibilities, the portrait is mostly 'a matter of relationality', Weiss cogently argues (81), it becomes 'a site of mediation and negotiation' (84) between subjects and their world. 
John's letters and notebooks carry signs of this relational matrix between portraits, subjects and the world. What I therefore suggest is that studying self-portraits alongside epistolary texts is a move beyond the limits of narratives: the self-portrait as a visual image destabilizes rather than complements narrative analysis and forces us to think differently about subjects and psychosocial relations. In thus making connections between John's self-portraits and epistolary narratives I will now trace genealogical lines of what I have called, John's farewell to the self, the process through which the sitter in general and herself in particular, became imperceptible in her work. In doing this, I will now take the third thematic path of this paper.

\section{Farewell to the Self}

I have been expecting for a long time to hear that you have received my picture, and I have been anxious to know whether you like it ... I think my picture is now at the bottom of the sea with the Titanic. I am hoping to hear from you that that is so. It is not as I want to paint like, and I now know a little more what I want to do. I shall send you the next picture I finish in the place of it. It will be better than the other. I like so little the other now that I hope I shall not hear of it again, except to hear that you have not received it and never will. ${ }^{9}$

In the above extract from a letter written to her American patron Quinn on August $5^{\text {th }}$, 1912, John expresses her dissatisfaction with her last recorded self-portrait, Girl Reading at the Window. So far I have presented a range of contradictory discussions and views around self-portraiture in general and this painting in particular; what I want to do now is to look closer into the conditions of its production. The painting was commissioned by Quinn, a great admirer of John's work and a source of permanent income and stability for the artist for fourteen years. As she was writing in acknowledgement of his support on November $28^{\text {th }}, 1911:$

It is so good of you to offer me another commission. I have felt this year, sometimes, that I have been taking advantage of your generosity. But if you had not paid me in advance I don't know when the picture would have been done, as it requires a quiet mind for me to paint, and I found myself in debt. I am not in want of money now. ${ }^{10}$

John had therefore worked hard for the Girl Reading, but it took her much longer to finish than she had initially anticipated. Once again her patron's patience was crucial in allowing her time to complete the work in a way that she was ultimately happy with. John acknowledged this in a letter written on August 22 $2^{\text {nd }}, 1911$ : 'Your picture is now done. I have done what you said I might do, taken my time over it. I have enjoyed doing it for that reason. Thank you so much for your letter telling me not to hurry over it. ${ }^{, 11}$ 
After its completion the painting travelled to London for the annual New English Club (NEAC) exhibition. Although living and working in Paris, John was regularly exhibiting in NEAC and definitely wanted to have feedback from the artists' community she trusted. This is revealed in a letter to Tyrwhitt written on November $18^{\text {th }}, 1911$ : 'Do send me another [letter of criticism] about this picture. I sent it there [NEAC] because I should never have known what it appeared like to people if it was sent off at once to Mr Quinn, who doesn't know anything about painting. ${ }^{, 12}$ The picture was indeed enthusiastically received as shown in the extract below from Tyrwhitt's reply, sent on November $16^{\text {th }}$ of the same year:

Your little picture is very well hung and much admired. It did not want any varnish. Ambrose McEvoy whose advice I asked said 'Don't touch it. It is most awfully good.' I think it is so like you and altogether delightful. Mary (McEvoy) and Ambrose and I stood looking at it and others came behind and we were quite a crowd all feeling do much pleasure from the sight of it. ${ }^{13}$

John was obviously very pleased with the reception of her work. This is what she was writing to her patron two days after receiving Tyrwhitt's letter above:

I sent the picture to London and they have hung it in the New English Art Club and I have several press notices about it. I don't know what they mean, but I suppose it means something. However I have heard from several artists who can really judge it that it has given me pleasure to see it, and I know it expresses something of what I feel so I am glad to send it to you. ${ }^{14}$

The painting took a long time to reach New York, where it finally arrived the following year. But by that time John had changed her mind about how she wanted to work; she was definitely going through a period of transformation as an artist, and her later paintings show very well how dramatically her technique would ultimately change. Quinn's enthusiastic letters ${ }^{15}$ about the reception of Girl Reading did not seem to change her mind:

Your little picture of Girl reading is invariably picked out in my apartment and immensely admired. People inquire who it is by and whether I have any other of yours. So you maybe sure I will be glad to get the other two. (18/3/1914)

Girl Reading at the window was therefore highly praised and admired both in London and in New York and it contributed to establishing John's reputation as an artist; it was indeed a prelude to her on-going career, but also a turning point in the development of her art techniques, her farewell to the self. I want to retrace this nomadic passage away from the self by going back to its moment of emergence, John's early self-portraits with which she made her debut in the world of art. 
Self-portrait ${ }^{16}$ now housed at the National Portrait Gallery, was the first work John ever exhibited after completing her studies at the Slade. It was shown in the NEAC Exhibition of 1900 and it was John's signature as the New Woman of modernity: young, assertive and powerful. Foster has noted $(2000,175)$ that this self-portrait was painted during or soon after John's first visit to Paris in winter 1899-1900. John went to Paris in the company of her two friends and fellow students at the Slade, Ida Nettleship and Gwen Salmond; the intention was to further their art education, a common trend for women artists from all over the world at the time. Being immersed in the Parisian artistic milieu the three young women were particularly drawn by the desire to participate in the creation of a new feminine artistic identity and all produced a series of self portraits, as well as portraits of each other.

During their stay in Paris the three women attended Whistler's Académie Carmen, which had just opened. Whistler was an influential teacher for John and it is no wonder that John's Self-Portrait, painted shortly after her visit to Paris, adopts as Foster notes, Whistler's pose in his self-portrait, Gold and Brown. ${ }^{17}$ (Foster 1999, 16) It is therefore in the context of affirming her artistic identity but also of experimenting with visual representations of the New Woman that John's first self-portrait should be considered and not as a reflection of how she perceived herself.

According to Foster's analysis then, in painting this first self-portrait John was clearly following the conventions of the portraits of the old masters as well as the trend of the revival of historical portraiture that well-known painters of her time like Sargent and Whistler had already initiated. (1999, 14-15) As it has been noted however, 'the self-portrait often repeats familiar conventions in portraiture but also creates scope for complex interpretation' (Rideal 2005, 7). Thus, conventional as it undoubtedly was, this first self-portrait was recorded and discussed as particularly powerful, already releasing forces of intensity that would later saturate the work of John's maturity. (Langdale 1987, 135)

Self-Portrait in a red blouse ${ }^{18}$ now housed at the Tate Gallery, soon followed (c.1900-1902) as a visual psychograph of the self-contained intellectual woman; it is John's only work with a signature and her first painting to be sold. Foster has pithily noted that as a young Slade student John was working within and beyond the conventions of her time expressing her already multifarious ways of experimenting with visual representations of herself (1999, 18). Indeed as Liz Rideal has suggested, for any artist, the very process of staring at her reflection in the mirror in preparation for a self-portrait, inevitably initiates a form of selfexamination. This process of mediation according to Rideal 'gives us a taste of the challenges facing the self-portrait artist: how to convey complexities of personality and talent while at the same time reflecting layers of conscious emotion and personal history.' $(2005,77)$

Being immersed in this process of self-examination, John actually ended up offering two very different visual images of herself as an artist within a year. Here of course one has to consider conditions of possibility for such stark differences to emerge in such a short period of time. Jordanova has noted that 'when artists portray themselves they mobilise their 
distinctive skills' $(2005,43)$; a self-portrait in this light can become a pictorial problem or even a motif through which the artist can display a range of qualities and techniques. 'A self-portrait might therefore be seen as a sample of work, a declaration of achievement, an occasion for showing off, a distinctive kind of display that has its own neat completeness by virtue of the artist and the sitter being one and the same.' (43) Although John's body and character are represented differently in her first two self-portraits, these differences might be more relevant to a possible attempt to display a diversity of approaches to the art of selfportrait rather than to a visual representation of different conceptions of herself. In this light I have refrained from psychologising John's self-portraits and I have rather focused on the particular way that the body of the artist is being represented. Here the choice of clothes emerges as a fascinating theme that runs though the whole line of John's selfportraits: I have thus been particularly attentive to her decisions on the clothes of the figures, carefully tracing the significant changes that are visible in her self-portraits.

Rideal has pointed out that 'the choice of clothing in portraiture-particularly selfportraiture-is crucial' $(2005,31)$; indeed the decision about how the artist should present herself is dependent both on artistic conventions and trends, but also on social norms and market oriented expectations. Of course decisions about clothes can either follow trends and adhere to norms and expectations or simply break them. John's choice of her clothes in her two first self-portraits is particularly interesting in this light.

Foster has discussed in detail how the practical separate blouse and skirt, the full sleeves of the blouse and the large bow in the costume of The Self-Portrait, constitutes the sitter and consequently the artist as the New Woman, conscious of her class and her recently acquired freedom, but simultaneously concerned with her appearance and knowledgeable about fashion. $(2000,179)$ In contrast, the composed figure of the Self-portrait in a red blouse seems to be rather indifferent to contemporary fashion: 'the neck ribbon, shawl and hairstyle seem mid-Victorian', Foster has commented $(1999,18)$, particularly pointing to the cameo brooch which although out of fashion at the time of the portrait, stands as the symbol par excellence of artistic identity. This careful and elaborate choice of clothes and poses in John's first self-portraits adheres to conventions and demands of classical portraiture and goes hand in hand with a painting technique that follows 'an academic layering system where colour and chiaroscuro (light and shade) are built over modelled underlayers of paint.' (Bustin, 2004, 196) Things would dramatically change however, when John left London and the influence of the Slade behind her.

In 1904 John moved to Paris and it was during the initial years there that she painted her room, her cat, friends and herself as she could rarely afford a model. The material conditions of self-portraiture should not be downplayed: painting herself was a flexible and feasible project for John, albeit a complicated one, given the endless possibilities for selfrepresentation. (Rideal, 2005, 8) John's early self-portraits in Paris follow the realistic style of the years after her graduation from the Slade. In The Artist in her room in Paris, ${ }^{19}$ painted between 1907 and 1909, John shows herself sitting in her room in a contemplative mood, while the hat left on the bed in the background emits signs of a woman having just re- 
turned or ready to go out, a woman who inhabits interior spaces, but is not restricted within them. Although explicitly a self-portrait, 'this picture is nonetheless characteristic in its rejection of the rhetorical self-portrait image', Taubman has noted. $(1985,112)$ The choice of clothes, the posture and the hairstyle, are all compositional elements particularly relevant to John's moving away from the style of the first portraits in the UK. One could say of course that many things had changed in John's life by then, but it is not so much biographical changes that this self-portrait represents, but rather a new technique that she was gradually adopting, 'a Spartan method of painting in one go.' (Bustin 2004, 196)

In the context of her life as a young artist in Paris and as a woman in love, John further created a series of nude self-portraits, ${ }^{20}$ partly as an attempt to please Rodin but also as a way to experiment with new material and techniques. John had difficulties in painting herself in the mirror, but how is this difficulty to be understood? The importance of the mirror in the artist's self-representation is of course a theme much discussed and analysed in the literature of self-portraiture. As succinctly summarized by Bond, 'in order to paint his own likeness the artist must be able to look into a mirror.' $(2005,32)$ However, who is able to look into a mirror and how much does gender intervene in constituting this ability or maybe 'disability' to do so? Meskimmon (1996) has influentially argued that 'the art of reflection' is a deeply gendered set of practices and discourses. Although the mirror is an immensely influential object in the history of self-portraiture, a sine-qua-non for the emergence and development of this sub-genre in art history, women's real and metaphorical relationship with the mirror has had a troubling genealogy. Rather than being subjects 'able to look into the mirror', women have been historically constituted as objects to be seen in the mirror, but also as mirrors holding man's image, as in Virginia Woolf's configuration: 'Women have served all these centuries as looking-glasses possessing the magic and delicious power of reflecting the figure of man at twice its natural size.' (in Meskimmon 1996, 5)

Despite this troubling history, feminist art historians have shown that women artists' relation to and use of the mirror in self-portraiture have opened up new and innovative paths in the history of the genre and Meskimmon's study of women artists' self-portraiture in the twentieth century has been influential in this rich body of literature. However what John's letter forcefully articulates is not just her difficulty in painting herself in the mirror but also the particular difficulty of painting herself nude in the mirror. As a Slade student, John had of course been trained in life drawing. Although innovative in allowing female students to draw from life, the Slade would impose certain segregations and restrictions: women would draw from a life model in a separate room, while their access to the model and particularly the female nude would be framed within certain discourses and practices that were both classed and gendered.

John's difficulty in painting herself nude in the mirror should therefore be considered within the constraints of her gender, class and culture, as well as her existential fears, her disillusionment with her relationship with Rodin and of course the artistic anxiety of developing new methods and techniques in her art. Of course by the time that John was ex- 
perimenting with her nude self-portraits many things had changed in her life and the class boundaries separating the model from the artist had definitely collapsed. What is particularly significant with John's nude self-portraits is that there is a series of five similar drawings where the artist and the naked model are bound together as a nude figure standing in the middle of her bedroom and drawing in a sketchbook.

In discussing Renée Sisternis' self-portrait, Drawing Nude, created in 1917, not long after John's drawing nudes above, Meskimmon has suggested that such works 'subvert the traditional association of woman-as-object in art by representing the woman artist nude and in the act of producing images.' $(1996,32)$ Meskimmon has also pointed to the fact that the two images brought together in the figure of the nude artist starkly visualize the dilemma that many women artists at the time would face in search of an identity.

\section{Painting the Self, Playing with the Self}

In this paper I have discussed entanglements between John's letters and self-portraits making interdisciplinary connections between discussions around portraiture and auto/biographical narratives. Questions around genres have emerged as crucial in this area: possibilities and limitations of self-portraiture as a sub-genre of life writing have been considered in the context of John's epistolary and visual archive. What I have tried to suggest is that 'the visual turn' (Riessman 2008) in narrative research needs to consider carefully discourses and debates in the field of visual studies and art histories. It is simply not enough to juxtapose visual images and textual narratives in making sense of a woman artist's life, a reductionist trend in the writing of artistic biographies, but also of art histories. In this light I have been particularly interested in Jordanova's suggestion that selfportraits display an immense variety of visual themes, poses and motifs that need to be compared and discussed in their interrelation. $(2004,46)$

In thus considering John's self-portraits I have traced her lines of flight ${ }^{21}$ from the constrained spaces and conventions of self-portraiture. Through her self-portraits which have been seen in the context of particular geographical, social, educational, artistic and cultural histories, but have also been discussed in relation to her letters, John follows nomadic paths in becoming an artist. Her self-portraits become events for playing with different modalities of self-representation and experimenting with other ways of painting the self. What happens I have thus asked, when instead of 'transforming one's life into a visual text readable by others' (Brockmeier 2001, 260) you turn it into a text unreadable by others? Or when you wrap it up with many layers of meanings and interpretations? The self in this context becomes irrelevant; it is only interesting as a figure expressing intensities and as a pictorial problem requiring solutions, a motif for experimenting with and bending the old masters' techniques. In looking into John's early practices of dismantling the face, I have therefore been particularly interested in her nude self-portraits, not just as experiments in life and in art, but also as fields releasing forces of defacialization, going beyond figuration and narration. 


\section{Archival Sources}

National Library of Wales, Archives, Gwen John's papers (NLW MS)

Rodin Museum, Marie Gwendolen John's boxes (MR/MGJ)

\section{References}

Brilliant, Richard. 1991. Portraiture. Cambridge, MA: Harvard University Press.

Brockmeier, Jens. 2001. 'From the end to the beginning: Retrospective teleology in autobiographt' In: Jens Brockmeier and Donal Carbaugh, Eds. Narrative and Identity Studies in Autobiography, Self and Culture. Amsterdam: John Benjamins Publishing, 247-280.

Bustin, Mary. 2004. 'The Rules or Problems of Painting: Gwen John's Later Painting Techniques'. In: David Fraser Jenkins and Chris Stephens, Eds. Gwen John and Augustus John. London: Tate publishing, 196-202.

Chitty, Susan. 1987. Gwen John. New York: Franklin Watts.

Deleuze, Gilles and Guattari, Felix. 1988 A Thousand Plateaus: Capitalism and Schizophrenia. Translated from the French by Brian Massumi. London: The Athlone Press. (Original work published 1980)

Figes, Eva. 1993. 'A lady reading (1909-11) by Gwen John'. In: Judith Collins and Elsbeth Lindner E. Eds. Writing on the wall: women writers on women artists, London, Weidenfeld and Nicholson, 71-76.

Foster, Alicia. 1999. Gwen John, London: Tate Gallery Publishing.

- . 2000. 'Gwen John's Self-Portrait: Art, Identity and Women Students at the Slade School'. In: David Peters Corbett and Lara Perry. Eds. English Art 1860 - 1914: Modern Artists and Identity. Manchester: Manchester University Press, 168-179.

Foucault, Michel. 2000. The Order of Things: An Archaeology of the Human Sciences. Translated from the French by Tavistock Publications. London: Routledge. (Original work published in 1966)

Jordanova, Ludmilla. 2004. 'The Body of the Artist'. In: Anthony Bond and Joanna Woodall, Eds. Self Portrait: Renaissance to Contemporary. London: National Portrait Gallery Publications and Sydney: Art Gallery of New South Wales, 43-55.

Koerner, Joseph Leo. 2005. 'Self Portraiture Direct and Oblique'. In: Anthony Bond and Joanna Woodhall, Eds. Self Portrait: Rennaissance to Contemporary. London: National Portrait Gallery and Sydney: Art Gallery of New South Wales, 67-81.

Langdale, Cecily. 1987. Gwen John, With a Catalogue Raisonné of the Paintings and a Selection of the Drawings. New Haven and London: Yale University Press.

Langdale, Cecily and Jenkins, David Fraser. 1985. Gwen John: An Interior Life. New York: Rizzoli.

Lloyd-Morgan, Ceridwen. 2004. Gwen John: Letters and Notebooks. London: Tate Publishing in association with the National Library of Wales.

Meskimmon. Marsha. 1996. The Art of Reflection: Women Artists' Self-Portraiture in the Twentieth Century. London: Scarlet Press.

Peirce Charles Sanders. 1991. 'Sign'. In: James Hoops, Ed. Peirce on Signs: Writings on Semiotic by Charles Sanders Peirce. Chapel Hill and London: The University of North Carolina Press, 239. 40. (Originally published in 1901)

Rideal, Liz. 2005. Self-Portraits. London: National Portrait Gallery Publications.

Riessman-Kohler, Catherine. 2008. Narrative Methods for the Human Sciences. London: Sage.

Roe, Sue. 2002. Gwen John, A Life. London: Vintage. 
Tamboukou, Maria. 2008. 'Re-imagining the narratable subject'. Qualitative Research, 8 (3), 283-292.

- 2010. 'Charting Cartographies of Resistance: Line of Flight in Women Artists' Narratives'. Gender and Education, 22 (6), 679-696.

forces'. Qualitative Research, 11 (5), 625-641.

_- 'Beyond figuration and narration: Deleuzian approaches to Gwen John's paintings', Deleuze Studies. (in press)

Taubman, Mary. 1985. Gwen John: The artist and her work. Ithaca: Cornell University Press.

Weiss, Gali. 2009. The Anonymous Portrait: A Creative and Critical Investigation of Diaspora, Portraiture, Subjectivity. Unpublished PhD thesis. Melbourne: Victoria University.

West, Shearer. 2004. Portraiture. Oxford: Oxford University Press.

Wolff, Janet. 1994. 'The Invisible Flâneuse: Women and the Literature of Modernity'. In Janet Wolff. Feminine Sentences, Essays on Women and Culture. Cambridge: Polity Press, 34-47.

Woodall, Joanna. 1996, Ed. Portraiture: Facing the Subject, Manchester and New York: Manchester University Press.

Woolf, Virginia. 1976. Jacob's Room. London: Panther. (Original work published in 1922)

\section{Notes}

$1 \quad$ NLW MS 21468D, ff.63-64.

2 Gwen John (1876-1939) was born in Wales, studied at the Slade and moved to Paris in 1904 where she lived and worked till the end of her life. Her long affair with Auguste Rodin has been discussed at length in her two biographies (Chitty 1987, Roe 2002) and a series of art history monographs (Langdale 1987, Taubman 1985, Foster 1999). See also Tamboukou 2011, for a discussion of her letters.

3 Langdale (1987, 38), pl.53, cat. no. 24.

Tate Gallery:

http://www.tate.org.uk/servlet/ViewWork?cgroupid=999999961\&workid=7144\&sear chid $=10545$

$4 \quad$ Ibid., pl. 54, cat. no. 25., The Museum of Modern Art (MoMA), New York. http://xroads.virginia.edu/ ${ }^{\sim}$ Museum/Armory/galleryP/john.578.html 
5 The Camden Town Group introduced Post-Impressionism to Britain. Key themes in their work were life in the city, people and style.

6 See West 2004, for an excellent overview and annotated bibliography of the literature around self-portraiture.

7 Entry in her notebooks of 8/2/1922. (Lloyd-Morgan 2004, 124)

8 See Shearer West $(2004,41)$. West points out to an interesting body of literature around Peirce's semiotics in relation to portraiture.

9 Langdale 2004, 76.

10 Ibid., 73.

11 Lloyd-Morgan 2004, 69.

12 NLW MS 21468, f.66.

13 Taubman 1985, 119.

14 Lloyd-Morgan 2004, 72.

15 Cited in Langdale 1987, 142.

16 Landgdale $(1987,16)$, pl.17, cat. no. 8.

National Portrait Gallery, London:

http://www.artfund.org/artwork/3687/gwen-john-selfportrait

17 See the portrait at:

http://www.fineartprintsondemand.com/artists/whistler/gold_and_brown_self_portra it.htm

18 Landgdale $(1987,18)$, pl.18, cat. no. 9. Tate Gallery:

http://www.tate.org.uk/servlet/ViewWork? cgroupid=999999961\&workid=7152\&sear chid $=10545$

19 Langdale, $(1987,30)$, pl.32, cat. no. 18. Private Collection:

http://www.wikigallery.org/wiki/painting_198028/Gwen-John/The-Artist-in-herRoom-in-Paris

20 Self-portrait nude, sketching, c.1908-09, pencil on paper (24.8x16.5), National Museum of Wales; Self-portrait, Naked, Sitting on a bed, c.1909, pencil and guache on paper (25.4x16.2) http://www.wikigallery.org/wiki/painting_198121/Gwen-John/Self-Portrait-Naked

21 'Lines of flight' is a concept from Deleuze and Guattari's (1988) philosophy, as their way of theorizing resistance. See Tamboukou 2010, for a discussion of 'lines of flight' in women artists' narratives. 